\title{
Quantitative and Morphological Effect of Plant Growth Regulators on Callus Initiation from Leaves and Roots Explants of Artemisia annua $L$.
}

\author{
Wajeeha Iffat ${ }^{1 *}$, Sohail Hussain ${ }^{2}$ \\ ${ }^{1}$ Department of Biotechnology, Jamia Hamdard, New Delhi, India \\ ${ }^{2}$ Department of Pharmacology, College of Pharmacy, Jazan University, \\ Kingdom of Saudi Arabia \\ *iffat_w@yahoo.com
}

Keywords: Artemisia annua, in vitro, explants, growth regulators

\begin{abstract}
To study the effect of some plant growth regulators on the in vitro initiation of callus using the leaves and roots explants of Artemisia annua. The experiment was arranged in a completely randomized design with 2 replicates. Morphologically leaf explants culture in media having the composition MS Basal + NAA $(2.0 \mathrm{mg} / \mathrm{l})+\mathrm{BA}(1.0 \mathrm{mg} / \mathrm{l})$ shows best results as compared to all other media. However in roots shows no growth in all the media composition. On the other hand media having a composition (MS Basal + 2,4-D(1.0mg/l) $+\mathrm{Kn}(0.1 \mathrm{mg} / \mathrm{l})$ ) with growth hormone antagonist shows no callus formation neither in leaf or roots. Our studies are also supported by the HPLC results about the artemisinin content in leaf in media having the composition MS Basal + NAA $(2.0 \mathrm{mg} / \mathrm{l})+\mathrm{BA}(1.0 \mathrm{mg} / \mathrm{l})$ is $0.052 \%$ and least in media a composition (MS Basal + 2,4-D(1.0mg/l) $+\mathrm{Kn}(0.1 \mathrm{mg} / 1))$ have only $0.012 \%$. On the other hand, we didn't found any artemisinin content in the root explants in all the media. Our present study suggest that Benzyl adenine (BA) could be used as a promising growth hormone in tissue culture.
\end{abstract}

\section{Introduction}

Now a day's most of biologically active molecules with biological activities such as antimicrobial, insecticidal dyes, flavors, fragrances, pigments, agrochemicals and pharmaceuticals are extract from plants. To gets these product throughout the years with high productivity of secondary metabolite researchers develops a technology known as Plant cell culture (Dicosmo and Misawa 1995).

Artemisia annua L. (Asteraceae), is a sources of aromatic product is an annually growing herb, known as Sweet Wormwood is cultivated in China as a medicinal plant. Due to a source of aroma chemicals forms leaves of Artemisia annua used in fragrance industry this plant is now cultivating recently in Europe and India. Type of pollination is cross by either wind or air having diploid with chromosome number, $2 n=18$. A portion of the naturally dynamic optional metabolites substantiate the case made in customary arrangement of prescription (Bhakuni et al. 2001).

Some exploration in the home grown medication prompts the improvement of new medication from A. annua, the wellspring of qinghaosu (artemisinin), an exacerbate that shows guarantee as an enemy of malarial specialist (Klayman 1985). Artemisinin likewise found as a plant inhibitor and herbicide (Pamela et al, 2011). Artemisinin has been appeared to specifically murder malignant growth cells and human disease. In the ongoing investigation, the viability of a consolidated treatment of dihydroartemisinin (DHA artemisinin simple) and butyric corrosive at low portions in murdering malignancy cells offered a less dangerous, modest, and successful disease chemotherapy. There have been energizing preclinical outcomes against leukemia (Mueller et al. 2004) and other disease cells.

The business wellsprings of most artemisinin are from field developed leaves and blossoming highest points of A. annua, which are exposed to regular and physical variety and pervasion of microorganisms, organisms, and bugs that can influence the utilitarian therapeutic substance of this plant (Klayman 1985). Constrained accessibility from enormous scale trimming of A. annua plants 
combined with extreme interest for the restorative has prodded researchers to investigate substitute strategies for generation.

Plant cell culture isn't influenced by changes in natural conditions, so improved generation might be accessible in wherever or season. A choice to field-developed harvests or to concoction amalgamation has been enormous scale in vitro plant tissue culture (Francois et al. 1990; Dhingra et al. 2000). Roots and buds are initiated by callus from poplar stems (Simon EF, 1990). White prompted callus got from tumor-creating procambial tissues of half breed Nicotiana that did not require hormone supplementation. Gautheret (1939) and Nobecourt (1939) had the option to keep up callus societies of carrot utilizing auxin hormone increases.

The Chinese antimalarial tranquilize artemisnin (Qinghaous, QUS) is one such new medication of current intrigue. Artemisinin has quick activity and is compelling against chloroquine-safe malarial parasites and has an alternate method of activity from existing blood schizonticides (Nair et al.1986). Artemisinin (qinghaosu) is a metabolite of Artemisia annua L, go about as a sesquiterpene lactone with antimalarial safe against Plasmodium spp. and flow inquire about additionally demonstrates that artemisinin medications are viable against disease (Efferth et al 2001), Leishmania (Yang and Liew, 1993; Sen et al., 2007), Trypanosoma (Mishina et al., 2007), and some infections (Romero MR 2005). The high antioxidative movement of A. annua is because of high substance of flavonoid. Likewise, A. annua leaves and rough concentrates have been accounted for to be a decent wellspring of cell reinforcements (Cai et al., 2004), being among the four therapeutic plants with the most elevated ORAC (oxygen radical absorbance limit) level among different medicinals (Zheng and Wang, 2001). High cancer prevention agent movement is because of the high substance of leaf flavonoids (Bilia et al., 2006), this might be credited to the newfound C-glycosyl flavonoids as a perhaps in charge of antioxidative and antiviral action (Han et al., 2008).

\section{Material and Methods}

Studies were carried out in the Department of Biotechnology, Jamia Hamdard, Delhi, India. The explants were sterilized and incubated on Murashige and Skoog basal media (MS medium, 1962). augmented with concentrations 0.5 to $1.0 \mathrm{mg} / \mathrm{l}$ of kinetin (kn), Benzyl adenine (BA), 2,4Dichloro Phenoxy Acetic Acid (2,4-D).

INOCULATION AND MAINTENANCE OF CULTURES: Callus cultures were initiated by transferring different explants (leaf, petiole, intermodal, nodal segments and roots) of 30 days old in vitro grown plants of Artemisia annua, on different callus initiation media with various growth regulators. The compositions of media used for callus induction and their effects on different explants are listed in Table -1 . The experiments were carried out in duplicate. The cultures were maintained at $25{ }^{\circ} \mathrm{C}$ and $16 / 8 \mathrm{Hr}$. light/dark regime. The cultures were maintained for 45 days and observations were recorded after every 5 days interval. After 45 days of culture, the artemisinin content $(\%)$ in each of the callus lines induced by various explants on different media was analysed by HPLC. Here we will show the results of only leaf and root explants Table -1 .

Table 1: List of various media enhanced with different development controllers utilized for callus enlistment

\begin{tabular}{|c|c|}
\hline Media & Composition \\
\hline 1 & MS Basal+NAA $(2.0 \mathrm{mg} / \mathrm{l})+\mathrm{Kn}(0.5 \mathrm{mg} / \mathrm{l})$ \\
\hline 2 & MS Basal+NAA $(2.0 \mathrm{mg} / 1)+\mathrm{Kn}(1.0 \mathrm{mg} / \mathrm{l})$ \\
\hline 3 & MS Basal+NAA $(2.0 \mathrm{mg} / 1)+\mathrm{BA}(0.5 \mathrm{mg} / \mathrm{l})$ \\
\hline 4 & MS Basal+NAA $(2.0 \mathrm{mg} / 1)+\mathrm{BA}(1.0 \mathrm{mg} / 1)$ \\
\hline 5 & MS Basal+2,4-D $(1.0 \mathrm{mg} / 1)+\mathrm{Kn}(0.1 \mathrm{mg} / 1)$ \\
\hline
\end{tabular}


NAA - Naphthalene Acetic Acid, Kn - Kinetin, mg - milligram, BA - Benzyl adenine, 2,4-D - 2,4Dichloro Phenoxy Acetic Acid, mg/L -milligrams per liter.

High Performance Liquid Chromatography Analysis: To break down the substance of artemisinin in the callus societies, the way of life were gathered and air dried altogether. These examples were gauged and put away. 1 gm dried example was powdered and removed with hexane $(10 \mathrm{ml} \mathrm{X} \mathrm{3)}$ at $400 \mathrm{C}$, with the difference in hexane after each $24 \mathrm{Hrs}$. The hexane parts were pooled and focused under diminished weight. The buildup acquired was defatted with acetonitrile. The encouraged fat was sifted through and the filtrate was focused under decreased weight. The buildup subsequently acquired was broken down in $2 \mathrm{ml}$ methanol $(\mathrm{MeOH}) .20 \mu \mathrm{l}$ aliquot from the arrangement was then utilized for making Q260, as artemisinin does not have any chromophore for UV discovery in HPLC and afterward it was settled unmistakably on HPLC. It was derivatized by first adding 3\% NaOH to each example, brooding the example in shaking water shower at $5{ }^{0} \mathrm{C}$ for $30 \mathrm{~min}$, cooling at $4{ }^{0} \mathrm{C}$ for $5 \mathrm{~min}$. At that point include $1 \mathrm{M} \mathrm{GAA}$ in $20 \% \mathrm{MeOH}$ and keep up the pH at 6.8 (Numonov et al., 2019).

Location and Quantification Of Artemisinin: Derivatized artemisinin (Q260) was settled through a switched stage section utilizing $\mathrm{MeOH}$ : $10 \mathrm{mM}$ phosphate support $(\mathrm{pH} 7.9)$ in the apportion of 60:40 as the portable stage at a consistent stream rate of $1 \mathrm{ml}$ with the identifier set at a wavelength of $260 \mathrm{~nm}$ utilizing HPLC hardware (Water Delta 600, USA).

\section{Results}

Among the various explants and media, leaf explants and Medium four with composition' $\mathrm{MS}+$ Sucrose $(30 \mathrm{~g} / \mathrm{L})+\operatorname{Agar}(8 \mathrm{~g} / \mathrm{L})+\mathrm{NAA}(2.0 \mathrm{mg} / \mathrm{l})+\mathrm{BA}(1.0 \mathrm{mg} / \mathrm{l})$ and cultured at $25^{\circ} \mathrm{C}$ and $16 / 8 \mathrm{hr}$ light/dark regime were found best for callus induction and artemisinin content. The observations for different explants viz. leaf, petiole, node, internode and root inoculated on 10 different mediums were recorded after 5 days interval but we present results of only leaf and roots explants in day $0,15,25$ and 45 in Table- 2 and 3.

Table 2

\begin{tabular}{|c|c|c|c|c|c|}
\hline \multirow[b]{2}{*}{$\begin{array}{c}\text { Duration } \\
\text { (days) }\end{array}$} & \multicolumn{5}{|c|}{ Leaf } \\
\hline & Media 1 & Media 2 & Media 3 & Media 4 & Media 5 \\
\hline 0 & Inoculation & Inoculation & Inoculation & Inoculation & Inoculation \\
\hline 15 & $\begin{array}{l}\text { Green in color with } \\
\text { swelling }\end{array}$ & $\begin{array}{l}\text { Yellowish } \\
\text { green } \\
\text { swelling }\end{array}$ & $\begin{array}{l}\text { Little green } \\
\text { yellow and } \\
\text { swelling }\end{array}$ & $\begin{array}{l}\text { Yellow, green } \\
\text { swelling }\end{array}$ & Green Swelling \\
\hline 25 & $\begin{array}{l}\text { Greenish yellow in } \\
\text { color with swelling }\end{array}$ & $\begin{array}{l}\text { Same as } \\
\text { above }\end{array}$ & $\begin{array}{l}\text { Yellow green }+ \\
\text { swelling }\end{array}$ & Yellow callus & Green Swelling \\
\hline 45 & Brown and Callus“ & $\begin{array}{c}\text { Yellow }+ \\
\text { Callus }\end{array}$ & $\begin{array}{l}\text { Callus initiation } \\
+ \text { green }\end{array}$ & $\begin{array}{l}\text { Light green } \\
\text { callus }\end{array}$ & NO GROWTH \\
\hline
\end{tabular}

Table 3

\begin{tabular}{|c|c|c|c|c|c|}
\hline \multirow{2}{*}{$\begin{array}{c}\text { Duration } \\
\text { (days) }\end{array}$} & \multicolumn{5}{|c|}{ Root } \\
\cline { 2 - 6 } & Media 1 & Media 2 & Media 3 & Media 4 & Media 5 \\
\hline 0 & Inoculation & Inoculation & Inoculation & Inoculation & Inoculation \\
\hline 15 & $\begin{array}{c}\text { Greenish } \\
\text { yellow with } \\
\text { swelling }\end{array}$ & $\begin{array}{c}\text { Yellow Green } \\
\text { Swelling }\end{array}$ & $\begin{array}{c}\text { Yellow, Brown } \\
+ \text { Swelling }\end{array}$ & $\begin{array}{c}\text { Yellow } \\
\text { Swelling }\end{array}$ & $\begin{array}{c}\text { Yellow } \\
\text { Swelling }\end{array}$ \\
\hline 25 & $\begin{array}{c}\text { Whitish Green } \\
+ \text { Callus }\end{array}$ & $\begin{array}{c}\text { Greenish white } \\
\text { with callus }\end{array}$ & $\begin{array}{c}\text { Yellow \& } \\
\text { Brown Swelling }\end{array}$ & NO GROWTH & Yellow \\
Swelling \\
\hline 45 & $\begin{array}{c}\text { Brownish } \\
\text { Callus }\end{array}$ & $\begin{array}{c}\text { Greenish } \\
\text { yellow Callus }\end{array}$ & $\begin{array}{c}\text { NO } \\
\text { RESPONSE }\end{array}$ & NO GROWTH & $\begin{array}{c}\text { NO } \\
\text { RESPONSE }\end{array}$ \\
\hline
\end{tabular}




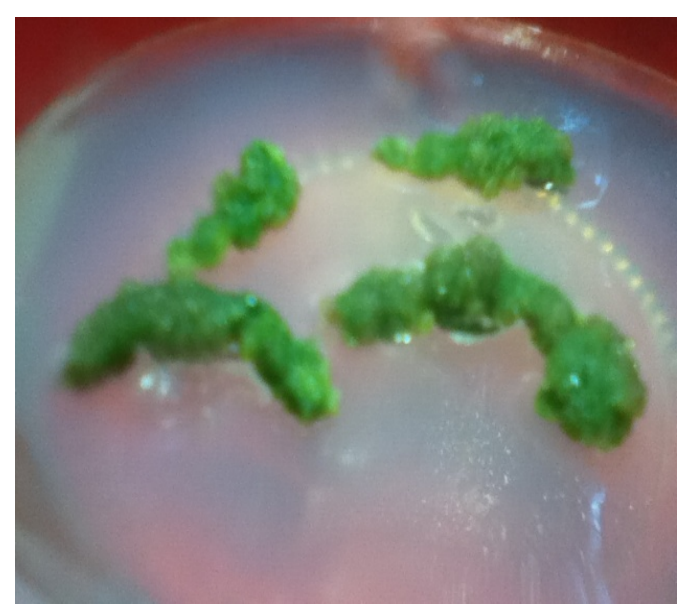

Leaf -1

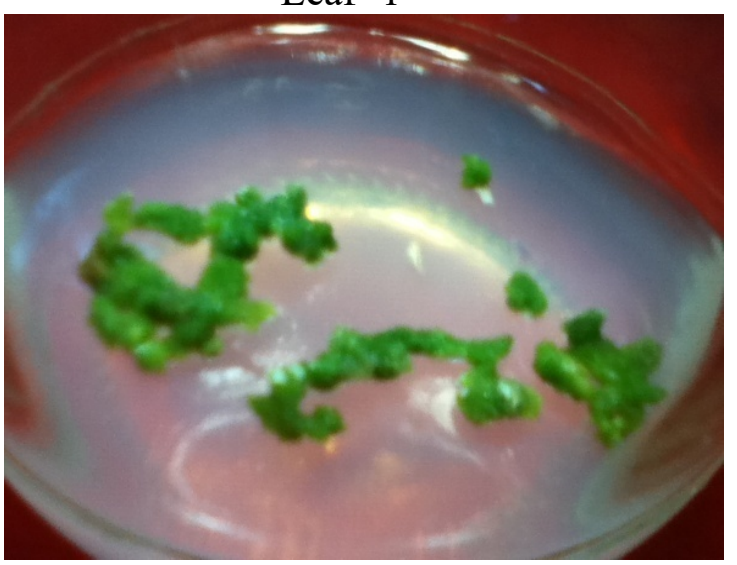

Leaf - 3

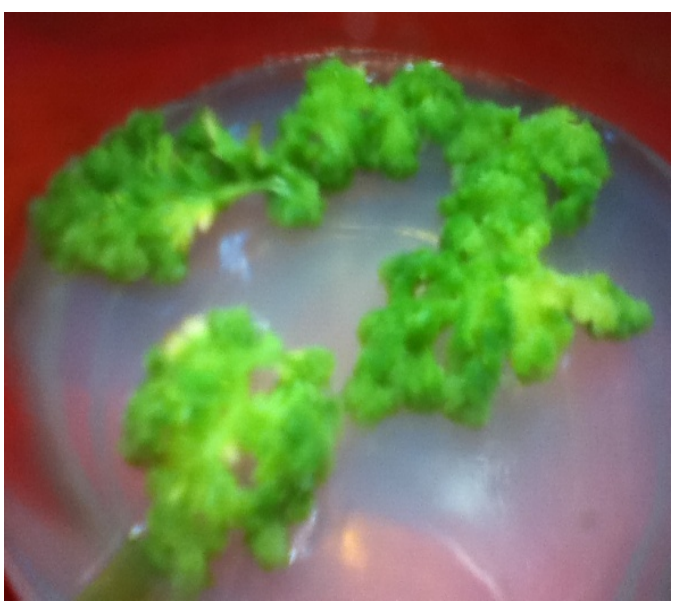

Leaf - 2

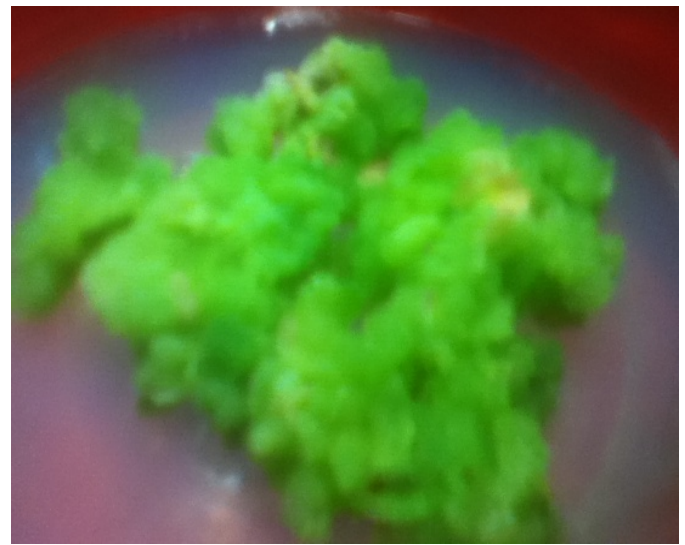

Leaf - 4

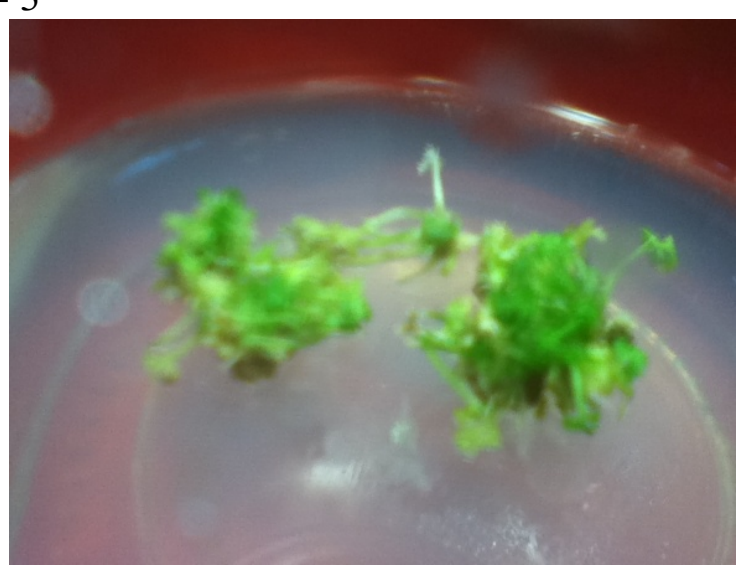

Leaf - 5

Figure 1: Leafs after 45 days of inoculation 


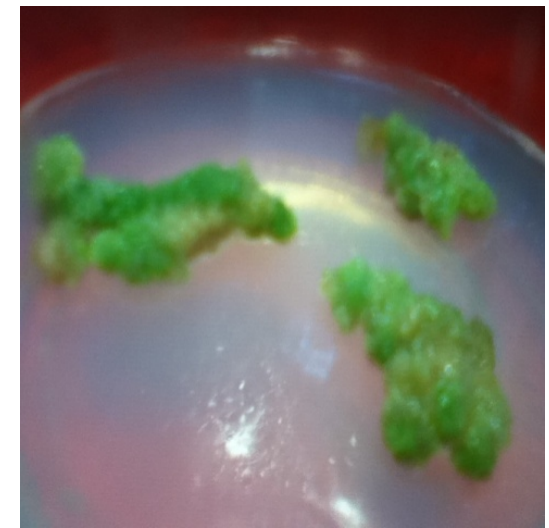

Root -1

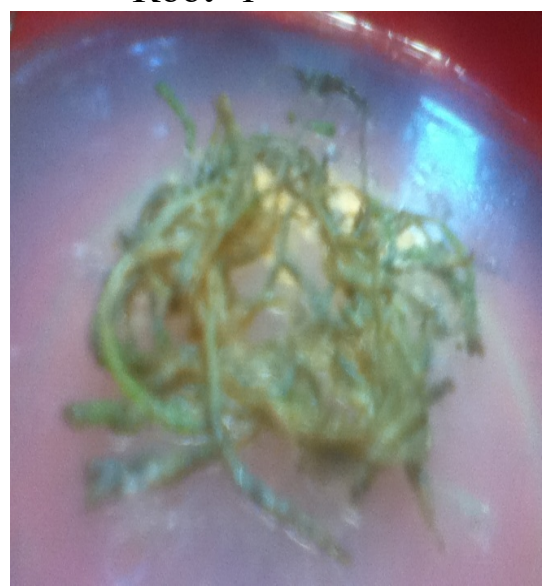

Root -3

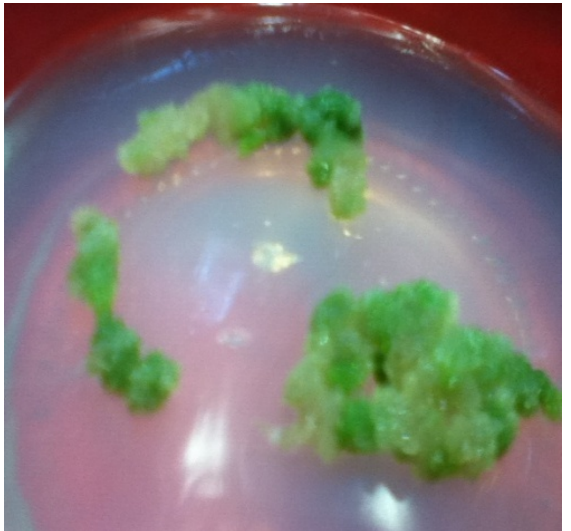

Root -2

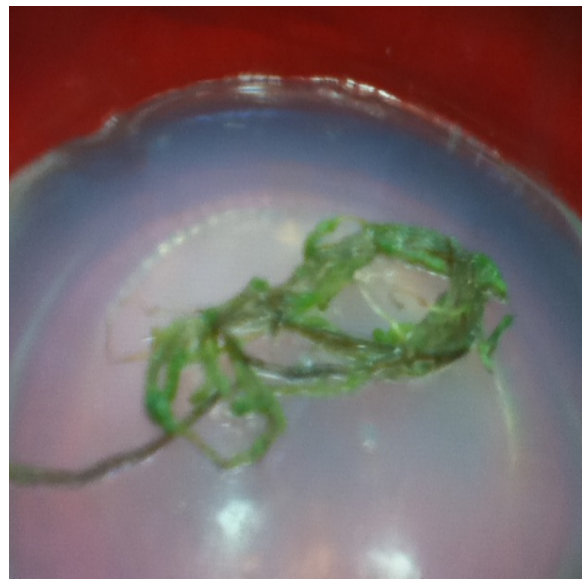

Root - 4

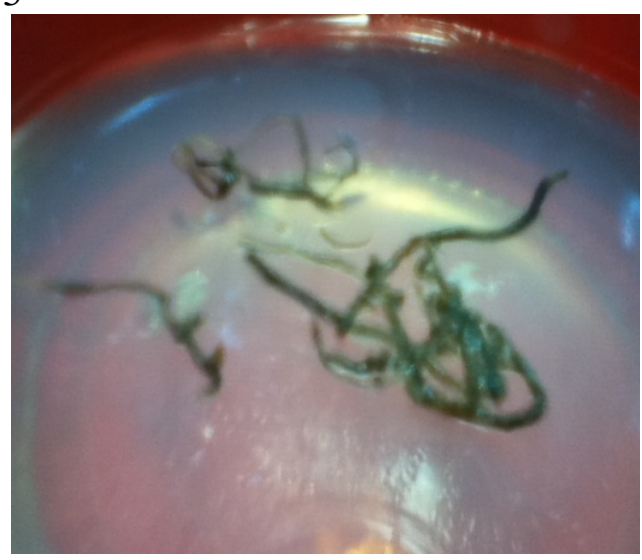

Root - 5

Figure 2: Roots after 45 days of inoculation

As observed the highest artemisinin content was found in callus line induced from leaf explants on medium 4 . The data is shown in table -4

Table 4: Depicting the artemisinin content in different callus cultures induced from various explants of Artemisia annua L. on different medium after 45 days of inoculation

\begin{tabular}{|l|l|l|l|}
\hline Medium & \multicolumn{1}{|c|}{ Composition } & \multicolumn{1}{c|}{ Leaf } & \multicolumn{1}{c|}{ Root } \\
\hline 1 & MS Basal + NAA(2.0mg/l)+Kn $(0.5 \mathrm{mg} / \mathrm{l})$ & $0.028 \%$ & - \\
\hline 2 & MS Basal + NAA(2.0mg/l)+Kn $(1.0 \mathrm{mg} / \mathrm{l})$ & $0.027 \%$ & - \\
\hline 3 & MS Basal + NAA(2.0mg/l)+BA $(0.5 \mathrm{mg} / \mathrm{l})$ & $0.049 \%$ & - \\
\hline 4 & MS Basal + NAA $(2.0 \mathrm{mg} / \mathrm{l})+\mathrm{BA}(1.0 \mathrm{mg} / \mathrm{l})$ & $0.052 \%$ & - \\
\hline 5 & MS Basal + 2,4-D $(1.0 \mathrm{mg} / 1)+\mathrm{Kn}(0.1 \mathrm{mg} / \mathrm{l})$ & $0.012 \%$ & - \\
\hline
\end{tabular}




\section{Discussion}

Among the explants viz., leaf and root, it can be concluded that the leaf explants gave the best response in terms of growth (fig-1) and artemisinin content in almost all media. During observations, medium (MS Basal + NAA $(2.0 \mathrm{mg} / 1)+\mathrm{BA}(1.0 \mathrm{mg} / \mathrm{l}))$ was found best interms of growth of callus from leaf explants. Callus initiated from leaf explants on medium number (MS Basal + NAA $(2.0 \mathrm{mg} / \mathrm{l})+\mathrm{BA}(1.0 \mathrm{mg} / \mathrm{l}))$ gave the highest artemisinin content of $0.052 \%$ whereas the lowest $(0.012 \%)$ was found in callus initiated on medium (MS Basal $+2,4-\mathrm{D}(1.0 \mathrm{mg} / \mathrm{l})+\mathrm{Kn}$ $(0.1 \mathrm{mg} / 1))$ (table-4). As evident from the observations, the hormonal interplay has a significant role in tissue culture. The choice of explants and the combination of hormones are the key factors influencing initiation of callus cultures. The study of growth pattern and increase in secondary metabolite content with respect to growth in callus lines is very essential. The ratio of increase in biomass and increase in artemisinin content with respect to time would be highly useful in further studies. This study will help in increasing the artemisinin production through callus culture by optimising the culture conditions. This can further be utilized for developing suspension cultures. The yield enhancement strategies, like the use compounds such as elicitors, growth regulators, precursors and permeabilising agents may further be employed for increased artemisinin production. The study of artemisinin content with respect to different explants has been crucial in screening out explants and media with better expression of artemisinin.

Almost all the explants, except root (fig-2), showed growth on various media. The leaf explants (fig-1) gave the best response in media number four and some growth in all other medium in terms of callus initiation as well as artemisinin content. As cited in literature, the commercial sources of most artemisinin are from field grown leaves and flowering tops of A. annua, this is also evident from our observations. The callus cultures initiated can further be exploited to develop cell suspension cultures. The suspension cultures can further be exploited to investigate the effects of various chemical factors on modulation of artemisinin production and to shed more light on regulation of artemisinin biosynthetic genes in response to specific compounds.

\section{Conclusion}

Most of biologically active molecules with biological activities such as antimicrobial, insecticidal dyes, flavors, fragrances, pigments, agrochemicals and pharmaceuticals are extract from plants. But to cultivate these plants throughout the year is not possible naturally so overcome this now researchers are depend on tissue culture. In present study a combined BA and NAA treatment is an efficient protocol for callus initiation and proliferation from explants using cultures of A. annua.

\section{References}

[1] Bhakuni RS, Jain DC, Sharma RP, Kumar S (2001). Secondary metabolites of. Artemisia annua and their biological activity. Curr. Sci. 80(1):35-48.

[2] Bilia AR, Melillo de Malgalhães P, Bergonzi MC, Vincieria FF (2006). Simultaneous analysis of artemisinin and flavonoids of several extracts of Artemisia annua L. obtained from a commercial sample and a selected cultivar. Phytomedicine 13:487-493.

[3] Cai Y, Luo Q, Sun M, Corke H (2004). Antioxidant activity and phenolic compounds of 112 traditional Chinese medicinal plants associated with anticancer. Life Sciences 74:2157-2184.

[4] DhingraV, Rao KV, Narasu ML (2000). Current status of artemisinin and its derivatives as antimalarial drugs. Life Sci. 66:279-300.

[5] Dicosmo F, Misawa M (1995). Plant cell and tissue culture: alternatives for metabolite production. Biotech. Adv. 13:425-435.

[6] Efferth T, Dunstan H, Sauerbrey A, Miyachi H, Chitambar CR (2001). The anti-malarial artesunate is also active against cancer. Int J Oncol. 18: 767-773. 
[7] Francois G, Desombere L, Hendricks L(1990). The production of antimalarial compounds by tissue cultures of Artemisia annua. Physiol. Plant. 79:A103.

[8] Gautheret R (1939). Sur la possibilité de réaliser la culture indéfinie des tissues de tubercules de carotte. C. R. Soc. Biol. Paris 208: 118-120.

[9] Han J, Ye M, Qiao X, Xu M, Wang B, Guo DA(2008). Characterization of phenolic compounds in the Chinese herbal drug Artemisia annua by liquid chromatography coupled to electrospray ionization mass spectrometry. Journal of Pharmaceutical and Biomedical Analysis 47:516-525.

[10] Klayman DL(1985). Qinghaosu (artemisinin): An antimalarial drug from China. Science228: 1049-1055.

[11] Mishina Y, Krishna S, Haynes RK, Meade JC (2007) Artemisinins inhibit Trypanosome cruzi and Trypanosomacruceirhodesiense in vitro growth. Antimicrob Agents Chemother 51:18521854.

[12] Mueller MS, Runyambo N, Wagner I, Borrmann S, Dietz K, Heide L(2004). Randomized controlled trial of a traditional preparation of Artemisia annua L. (Annual Wormwood) in the treatment of malaria. Transactions of the Royal Society of Tropical Medicine and Hygiene 98:318-321.

[13] Murashige T,SkoogF (1962). "A Revised Medium for Rapid Growth and Bio Assays with Tobacco Tissue Cultures". PhysiologiaPlantarum. 15 (3): 473-497.

[14] Nair M S R, Action N, Klayman D L, Kendrick K, Basile DV,Mante S (1986). Production of artemisinin in tissue cultures of Artemisia annua. J. Nat. Prod. 49: 504-507.

[15] Nobécourt P. (1939). Sur la pérennitéetl'augmentation de volume des cultures de tissues végétaux. Compt. Rendus Soc. Biol. Lyon 130: 1270-1271.

[16] Numonov S, Sharopov F, Salimov A, Sukhrobov P, Atolikshoeva S , Safarzoda R, Habas $M$ and Aisa HA (2019). Assessment of Artemisinin Contents in Selected Artemisia Species from Tajikistan (Central Asia). Medicines , 6, 23.

[17] Romero MR, Efferth T, Serrano MA, Castano B, Macias R, Briz O, Marin JJ (2005). Effect of artemisinin/artesunate as inhibitors of hepatitis B virus production in an 'in vitro' system. Antiviral Res. 68:75-83.

[18] Sen R, Bandyopadhyay S, Dutta A, Mandal G, Ganguly S, Saha P, Chatterjee M (2007) Artemisinin triggers induction of cell-cycle arrest and apoptosis in Leishmaniadonovanipromastigotes. J Med Microbiol 56:1213-1218.

[19] Simon JE. Charles D, Cebert E, Grant L, Janick J, Whipkey A (1990). Artemisia annua L.: A promising aromatic and medicinal. In Advances in new crops. Janick J, Simon JE, editors. Portland: Timber Press; 522- 526.

[20] Weathers PJ, Arsenault PR, Covello PS, Reed W (2011). Artemisinin production in Artemisia annua: studies in planta and results of a novel delivery method for treating malaria and other neglected diseases. Phytochem Rev. 10(2): 173-183.

[21] Yang DM, Liew FY (1993). Effects of qinghaosu (artemisinin) and its derivatives on experimental cutaneous leishmaniasis. Parasitology 106:7-11.

[22] Zhao S, Zeng MY (1985). Application of spectrometric HPLC to analysis of qinghaosu. Planta Med 91:233-237.

[23] Zheng W, Wang Y(2001). Antioxidant activity and phenolic compounds in selected herbs. Journal of Agricultural and Food Chemistry 49:5165-5170. 